\title{
The Jurassic Thalattosuchia (Crocodyliformes) of Chile : a paleobiogeographic approach
}

\author{
ZULma GASPARINI ${ }^{1}$, PATRICK VIGNAUD ${ }^{2}$ and GUILLERMO CHONG ${ }^{3}$
}

Key words. - Jurassic, Thalattosuchia, Chile, Systematic, Paleobiogeography.

Abstract - The thalattosuchian fossils from the Jurassic of Chile are revised. Some specimens, dating from the Lower Lias (Sinemurian), are the oldest known thalattosuchians, but are too fragmentary to establish a precise taxonomic placement. New specimen related to the genus Metriorhynchus is described from the lower Bajocian. It is the oldest representative of the genus and fills an important gap in our knowledge of the paleogeographic history of this group. Other new cranial fragments, related to the Callovian species Metriorhynchus casamiquelai, are described and this species is revised in the light of new studies on the intraspecific variability in extant crocodilians. Up until now, the known distribution of Liassic Thalattosuchia suggested a circumpacific distribution with minimally episodic passages through the Caribbean Corridor. Nevertheless, the close affinities between the South American and the European Metriorhynchidae from the Callovian to the Tithonian suggest the possibility that more and more frequent communications were made via the Caribbean Corridor. The new data corroborate the hypothesis formulated from the invertebrate faunas.

\section{Les Thalattosuchia (Crocodylomorphes) du Jurassique du Chili : une approche paléobiogéographique}

Mots clés. - Jurassique, Thalattosuchia, Chili, Systématique, Paléobiogéographie.

Résumé - La révision des Thalattosuchia du Jurassique chilien est réalisée. Certains restes, datés du Lias inférieur (Sinémurien) correspondent aux plus anciens thalattosuchiens connus mais sont encore trop fragmentaires pour permettre une définition précise. Un nouveau crâne, rapporté au genre Metriorhynchus, est décrit dans le Bajocien inférieur. Il s'agit du plus ancien représentant du genre et permet ainsi de combler une importante lacune de connaissance dans l'histoire paléobiogéographique du groupe. De nouveaux fragments de crânes, rapportés à l'espèce callovienne Metriorhynchus casamiquelai sont décrits et la révision de cette espèce est proposée à la lumière des récents travaux sur la variabilité intraspécifique chez les crocodiliens. La répartition actuellement connue des Thalattosuchia liasiques suggère une dispersion circum-pacifique avec passages, au moins épisodiques, par le Corridor caraïbe. A partir du Callovien, et jusqu'à la fin du Jurassique, les fortes similitudes anatomiques entre les Metriorhynchidae sud-américains et ouest-européens suggèrent la possibilité de communications de plus en plus fréquentes par le Corridor caraïbe. Ces nouvelles données corroborent les hypothèses formulées à partir des faunes d'invertébrés.

\section{VERSION FRANÇAISE ABRÉGÉE}

Dans le Jurassique inférieur d'Amérique du Sud, les restes de reptiles marins sont encore très rares et fragmentaires. Par contre, la découverte de nombreux reptiles (ichthyosaures, plésiosaures, crocodiliens métriorhynchidés et tortues) lors de récentes fouilles dans le Jurassique moyen et supérieur du Bassin de Neuquén (Chili-Argentine, fig. 1) permet de montrer les importantes affinités taxonomiques des faunes sud-américaines et européennes et de préciser leurs relations paléobiogéographiques. Parmi les thalattosuchiens, les plus anciens représentants du genre Metriorhynchus dans le Bajocien inférieur et de nouveaux restes post-calloviens permettent d'apporter un nouvel éclairage sur la dispersion paléogéographique de ces formes.

La présence de Thalattosuchia dès le Sinémurien du Chili est signalée par Chong-Diaz et Gasparini [1972] mais ces restes de métatarsiens sont très fragmentaires (fig. 2), et ne permettent pas une définition taxonomique plus précise. Par contre, le réexamen de la position des orbites et du développement des préfrontaux sur un fragment de crâne provenant du Bajocien inférieur et initialement rapporté à Ichthyosaurus acutirostris par Tavera [1981] montre qu'il s'agit en fait du plus ancien représentant connu du genre Metriorhynchus (fig. 3).

La découverte de nouveau matériel dans le Callovien moyen et la prise en compte des données issues de l'étude de la variabilité intraspécifique chez les crocodiliens actuels [Vignaud, 1995] permettent de préciser les affinités phylogénétiques de l'espèce Metriorhynchus casamiquelai (fig. 4 et 5). La validité de cette espèce fut contestée par AdamsTresman [1987] en raison notamment de l'existence d'intermédiaires entre les caractères distinguant $M$. casamiquelai de M. brachyrhynchus comme par exemple l'ornementation des os crâniens et la forme de la suture prémaxillaire / maxillaire. Les caractères diagnosiques sont donc discutés puis redéfinis. Parmi les autapomorphies de l'espèce, la distance séparant les prémaxillaires des nasaux, l'absence d'ornementation sur les préfrontaux, la forme du frontal et des narines internes entièrement cloisonnées permettent de distinguer $M$. casamiquelai des formes brévirostres européennes telles que $M$. brachyrhynchus. L'espèce sud-américaine $M$. westermanni fut créée sur un crâne incomplet et mal préservé (fig. 6). Le réexamen des caractères montre que certains d'entre eux peuvent être interprétés comme correspondant à des caractères juvéniles (orientation de la face occipitale, forme du pilier postorbitaire) alors que l'absence de division des narines internes est en fait due à la médiocre conservation du matériel. L'holotype de $M$. westermanni est interprété comme un spécimen juvénile et l'espèce $M$. westermanni doit donc être mise en synonymie avec l'espèce M. casamiquelai.

\section{Approche paléobiogéographique}

Dans le Jurassique inférieur, la distribution des restes de Thalattosuchia montre que ces formes peuplaient les bordures de la Téthys et la bordure est du Paléopacifique (France, Inde, Chine, Chili et Argentine). Les données anatomiques et

${ }^{1}$ Departamento de Paleontología Vertebrados, Museo de La Plata, 1900 La Plata, Argentina.

2 Laboratoire de Géobiologie, Biochronologie et Paléontologie Humaine, CNRS EP 1596, Université de Poitiers, 40 avenue du Recteur-Pineau, F-86022, Poitiers, France.

${ }^{3}$ Departamento de Geociencias, Universidad Católica del Norte. Casilla 1280, Antofagasta, Chile.

Manuscrit déposé le 11 janvier 2000 ; accepté après révision le 29 juin 2000. 
l'analyse sédimentologique des gisements indiquent clairement que ces premiers Thalattosuchia devaient être encore très inféodés aux milieux littoraux. Leur dispersion à travers le Paléopacifique paraît donc très improbable. Comme le montrent les affinités entre certaines faunes d'invertébrés (céphalopodes, lamellibranches, brachiopodes et ostracodes) d'Europe occidentale et d'Amérique du Sud [Schmidt-Effing, 1976; Hillebrandt, 1981; Hallam, 1983; Manceñido and Dagys, 1992; Boomer and Ballent, 1996; Rubilar, 1998; Jakobs and Smith, 1998; Liu et al., 1998], la présence d'une mer épicontinentale, nommée Corridor hispanique ou Corridor caraïbe, est probable dès le Jurassique inférieur bien que non documentée dans les sédiments. Ainsi, ce bras de mer aurait pu constituer un passage privilégié facilitant la dispersion des Thalattosuchia.

Dans le Jurassique moyen, les premiers représentants du genre Metriorhynchus sont connus dès le Bajocien inférieur du Chili et peut-être même dès l'Aalénien de l'Orégon [Stricker et Taylor, 1989]. En Europe occidentale, les restes de Teleosauridae sont fréquents mais parmi les Metriorhynchidae, seul le genre Teleidosaurus est représenté au Bajocien et Bathonien; les premiers spécimens rapportés au genre Metriorhynchus ne sont datés que du Callovien inférieur [Vignaud et al., 1994]. Dès le Bajocien, la présence de sédiments marins au Vénézuela [Bartok et al., 1985] atteste l'existence d'un bras de mer séparant l'Amérique du Nord de l'Amérique du Sud. Cette communication marine est confirmée par les importantes affinités taxonomiques des faunes d'invertébrés entre l'Europe et la bordure Pacifique de l'Amérique du Nord et du Sud [Westermann et Riccardi, 1985; Manceñido et Dagys, 1992; Rubilar, 1998]. Parmi les Metriorhynchidae, les affinités taxonomiques sont très importantes dès le Callovien moyen $(M$. brachyrhynchus en Europe et $M$. casamiquelai en Amérique du Sud) et jusqu'au Tithonien (Geosaurus et Dakosaurus). Durant cette période, les Teleosauridae sont restreints à l'Europe occidentale. Jusqu'à la fin du Jurassique, la dispersion des Metriorhynchidae et de certains autres reptiles marins est favorisée par la fragmentation du Gondwana et l'ouverture de voies de communication marines [Gasparini, 1992; Gasparini et Fernández, 1997].

\section{INTRODUCTION}

The largest number and greatest taxonomic diversity of Jurassic marine reptiles is found in Europe. Outside of Europe the records are both temporally and geographically scant, except for the herpetofauna from western South America in northern Chile and central-western Argentina (Neuquén Basin) (fig. 1). In these regions, the record ranges from the Hettangian to the Tithonian, with a significant taxonomic diversity in the middle Jurassic (ichthyosaurs, plesiosaurs and metriorhynchid crocodiles) as well as in the Tithonian (the three mentioned groups plus the only marine turtles from the eastern Pacific) [Gasparini and Fernández, 1996, 1997]. Most of these reptile taxa are related to European forms. This fact prompted one of us to propose different paleobiogeographic hypothesis [Gasparini, 1985, 1992].

The record of marine reptiles from the early Jurassic in western South America is very poor due to the lack of methodical field work. The material is fragmentary and most of what has been cited up to 1970 has been lost [Casamiquela, 1970; Chong-Diaz and Gasparini, 1976; Gasparini, 1985]. Consequently the taxonomic information is limited. However, intensive work in early Bajocian exposures of the Neuquén Basin yielded the greatest diversity hitherto known of marine forms from the middle Jurassic (pre-Callovian). These forms are transitional between those from the European Liassic and Dogger, covering part of the gap in the knowledge of the evolution and geographic distribution of plesiosaurs and ichthyosaurs [Gasparini, Spalletti and Fernández, 1997; Fernández, 1997; Gasparini, 1997].

In the Callovian formation of northern Chile and the Neuquén Basin, the reptiles are closely related to those of western Europe, especially from the Oxford Clay (Metriorhynchus, cf. Muraenosaurus, cf. Cryptoclidus). Consequently, the South American herpetofauna is especially significant from a paleobiogeographic standpoint [Gasparini and Chong-Diaz, 1977; Gasparini and Spalletti, 1993]. Finally, except for unconfirmed reports of ichthyosaurs and plesiosaurs from the Oxfordian and Kimmeridgian of Chile [Chong-Diaz and Gasparini, 1976], all the marine reptiles from the late Jurassic of western South America are from Tithonian sediments from the Neuquén Basin, that includes Lo Valdés area in central-west Chile. Taxonomic studies of these off-shore forms led to the proposal of paleogeographic
FIG. 1. - Map of Chile with Jurassic marine crocodilian localities (symbol).

FIG. 1 - Carte du Chili et localisation des sites à crocodiliens marins du Jurassique.

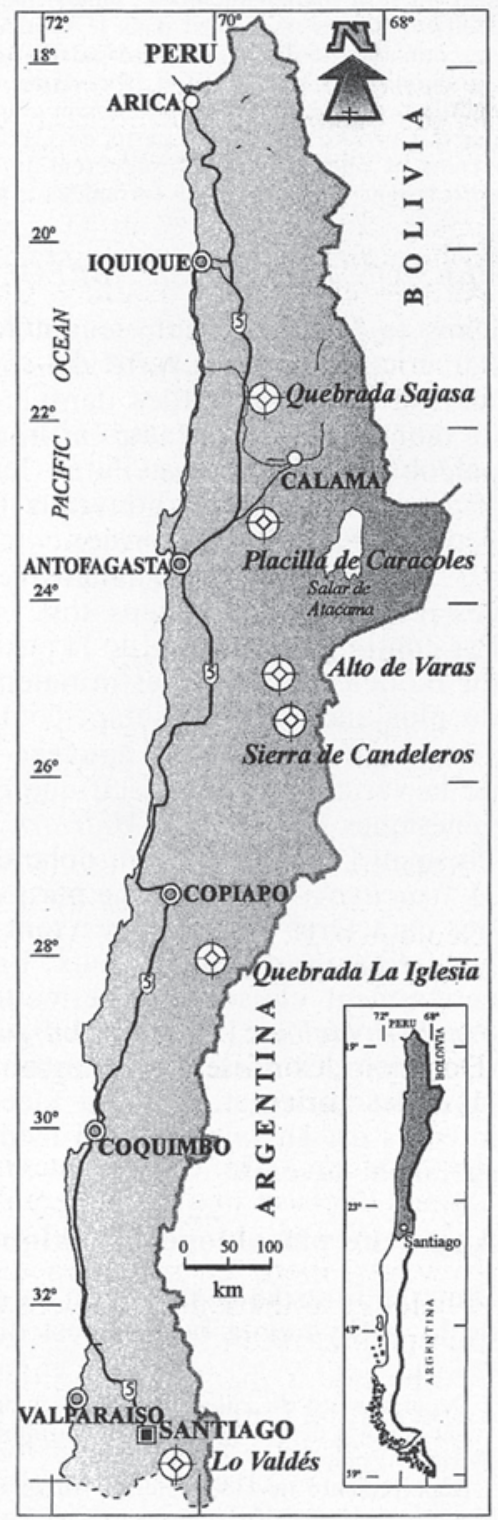


FIG. 2. - MGHF 3601 (87-1) Thalattosuchia indet., metatarsals 1-4, Sinemurian, scale bar: $2 \mathrm{~cm}$.

FIG. 2. - MGHF 3601 (87-1) Thalattosuchia indet., métatarses 1-4, Sinémurien, barre d'échelle: $2 \mathrm{~cm}$.

distribution hypotheses and paleoenvironmental analyses [Gasparini and Fernández, 1997; Gasparini Spalletti and de la Fuente, 1997; Gasparini et al., 2000].

In this context, the paleofauna from Chile is particularly interesting. It includes, the oldest marine crocodilian known in the eastern Pacific domain [Chong-Diaz and Gasparini, 1972], and the first undoubted Callovian metriorhynchid outside of western Europe [Gasparini and Chong-Diaz, 1977]. The discovery of new material of Metriorhynchus sp. from early Bajocian cited in this paper is the oldest record of this genus. Therefore, Chilean crocodilians from the early and middle Jurassic complete the knowledge of South American forms focussed mainly in those of the Tithonian of Neuquén Basin.

The objectives of this paper are : the taxonomic review of Jurassic crocodilians from Chile, the reassignment of the Bajocian materials originally referred to Ichthyosauria [Tavera, 1981] to the Metriorhynchidae, and the analysis of the paleobiogeographic significance of these records.

\section{Systematic paleontology}

Crocodyliformes Clark [in Benton and Clark, 1988] Thalattosuchia FRAAS, 1902

Gen. et sp. indet. (fig. 2)

Material. - MGHF 3601 (87-1). Right metatarsals 1-4 [Chong-Diaz and Gasparini, 1972]. MGHF: Museo Geológico H. Fuenzalida, Universidad Católica del Norte, Antofagasta, Chile.

Geographic and stratigraphic provenance. - Alto de Varas,

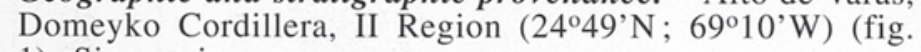
1). Sinemurian.

Discussion. - The four metatarsals are joined in natural position. Because of its stratigraphic position, it was tentatively referred to the Teleosauridae [Gasparini, 1985]. However, there are no characters for determining whether it belongs to the families Teleosauridae or Metriorhynchidae [Gasparini, 1996].

The oldest marine crocodilians known are from the Sinemurian of Lorraine, France [Huene and Maubeuge, 1952, 1954] and the Sinemurian of northern Chile. Other Liassic (s.l.) remains have been found in several localities of central Chile and Argentina [Gasparini, 1985], in the Kota Forma-

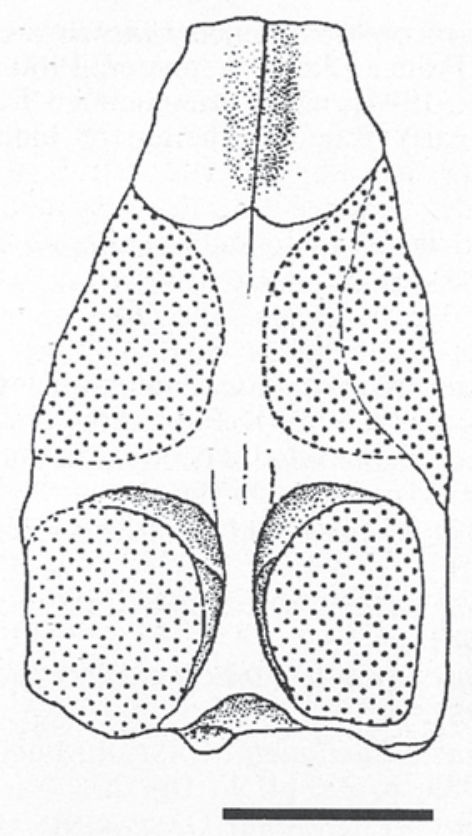

FIG. 3. - T 330 Metriorhynchus sp., posterior part of a skull in dorsal view, early Bajocian, scale bar: $5 \mathrm{~cm}$.

FIG. 3. - T 330 Metriorhynchus sp., partie postérieure d'un crâne en vue dorsale, Bajocien inférieur, barre d'échelle : $5 \mathrm{~cm}$.

tion of India [Krishna, 1987; Kutty et al., 1987], and in the Ziliujing Formation (upper Lias ?) in the Sichuan Basin of China [Li, 1993]. Except for the Teleosauridae Peipehsuchus teleorhinus (YOUNG, 1948) of the Sichuan Basin, the remaining Liassic crocodilians are represented by fragmentary materials, and consequently the taxonomic determinations, even at familial level, are dubious.

\section{Metriorhynchidae Fitzinger, 1843 \\ Metriorhynchus MEYER, 1830 \\ Metriorhynchus sp. (fig. 3)}

Material. - T 330. Small badly preserved skull [Tavera, 1981, Pl.I]. Department of Geology and Geophysics, Facultad de Ciencias Físicas y Matemáticas, Universidad de Chile, Santiago.

Geographic and stratigraphic provenance. - Quebrada La Iglesia, $100 \mathrm{~km}$ SSE from Copiapo, III Region (28 $07^{\prime} \mathrm{S}$; $69^{\circ} 58^{\prime} \mathrm{W}$ ) (fig. 1). Upper part of the Lautaro Formation (Seggerstrom), assigned by Jensen and Vicente [1976] and Hillebrandt [1977] to the early Bajocian.

Discussion. - Tavera [1981, Pl. I, 1-3] described part of a badly preserved skull, and referred it to Ichthyosaurus acutirostris OWEN. However, the specimen belongs to a marine crocodilian. The material was not prepared and much of the bones had been removed by erosion, leaving the filling of the cavities such as the orbits, the supratemporal fenestrae and the inside of the prefrontals exposed. This fact may have caused the misinterpretation by Tavera. Notwithstanding, these fillings, in dorsal and right lateral views, demonstrate the lateral position of the orbit and the expansion and lateral enlargement of the prefrontals, both synapomophies of the Metriorhynchidae. The supratemporal fenestrae are subcircular, slightly shorter than the orbits, and the dorsal bars of the postorbitals and the squamosals give them the quadrangular frame characteristic of the Metriorhynchidae [Vignaud, 1995]. 
The oldest records of Metriorhynchus are from the early Callovian of France [Kuhn-Schnyder, 1960; Brunet, 1969; Vignaud et al., 1994], while the specimen T 330 from northern Chile is early Bajocian, being the oldest specimen of the genus.

\section{Metriorhynchus casamiquelai \\ GASPARINI and CHONG-DIAZ, 1977 \\ (figs. 4, 5, 6)}

Metriorhynchus casamiquelai nov. sp.; GASPARINI and CHONG-DiaZ, 1977, p. 341, Figs. 2-5.

Metriorhynchus casamiquelai GASPARINI and CHONG-DIAZ; Gasparini, 1978, p. 4, pl. 1, fig. A.

Metriorhynchus westermanni GASPARINI; Gasparini, 1980, p. 97. pl. I, II.

Metriorhynchus casamiquelai GASPARINI and CHONG-DIAZ; Gasparini, 1981, p. 181.

Metriorhynchus casamiquelai GASPARINI and CHONG-DIAZ; Buffetaut, 1982, p. 28.

Metriorhynchus casamiquelai GASPARINI and CHONG-DIAZ; Gasparini, 1985, p. 28, pl. 1; fig. 2.

Metriorhynchus westermanni GASPARINI; Gasparini, 1985, p. 28 , pl. 1 ; fig. 3 .

Metriorhynchus casamiquelai GASPARINI and CHONG-DIAZ; Adams-Tresman, 1987, pp. 192-193.

Metriorhynchus casamiquelai GASPARINI and CHONG-DIAZ; Gasparini, 1992, p. 361.

Metriorhynchus westermanni GASPARINI; Gasparini, 1992, p. 361 .

Metriorhynchus casamiquelai GASPARINI and CHONG-DIAZ; Vignaud, 1995 , pp. 222-223, pp. 228-229.

Metriorhynchus casamiquelai GASPARINI and CHONG-DIAZ; Gasparini, 1996, pp. 162, 163, 171, 181.

Metriorhynchus casamiquelai GASPARINI and CHONG-DIAZ; Gasparini and Fernández, 1996, p. 445.

Metriorhynchus casamiquelai GASPARINI and CHONGDiAZ; Hua, 1997, pp. 133, 135.

Material. - Holotype MGHF 1-08573. Currently the Museo Fuenzalida at the Universidad Católica del Norte, Antofagasta, Chile. Skull with mandible (Figs. 4 a-c)

Geographic and stratigraphic provenance. - Quebrada Sajasa, $70 \mathrm{~km}$ NNE from Chuquicamata, El Loa Department, II Region (21 ${ }^{\circ} 46^{\prime} \mathrm{S}$; $\left.69^{\circ} 15^{\prime} \mathrm{W}\right)$ (fig. 1). Middle Callovian [Gasparini and Chong-Diaz, 1977].

Emended diagnosis. - The skull is massive with a broad and short rostrum. The distance between premaxillae and nasals is proportionally long. It is 12 percent the skull length and 33 percent the width between quadrates. In $M$. brachyrhynchus these values are 4-6 percent (on nine specimens) and 9-18 percent (on eight specimens), respectively. No ornamentation is present on frontal and prefrontals. The supratemporal fossae are quadrangular and the postorbital arcades are massive. The frontal is very wide between the orbits, and its posterior width, completely perpendicular to the anteroposterior axis of the skull, is considered an autapomorphy of this species. The orbit is circular, the lacrimal and the antorbital foramen are well developed. The internal nares are completely separated and closed posteriorly, this latter character also considered an autapomorphy. The pterygoid fossae are as wide as long. The foramina of the occipital face are large. The dental formula is $20-21 / 20-23$.

Referred material. - MGHF 1-181097. Anterior part of a large skull (fig. 5), from Sierra Candeleros (fig. 1), Callo-
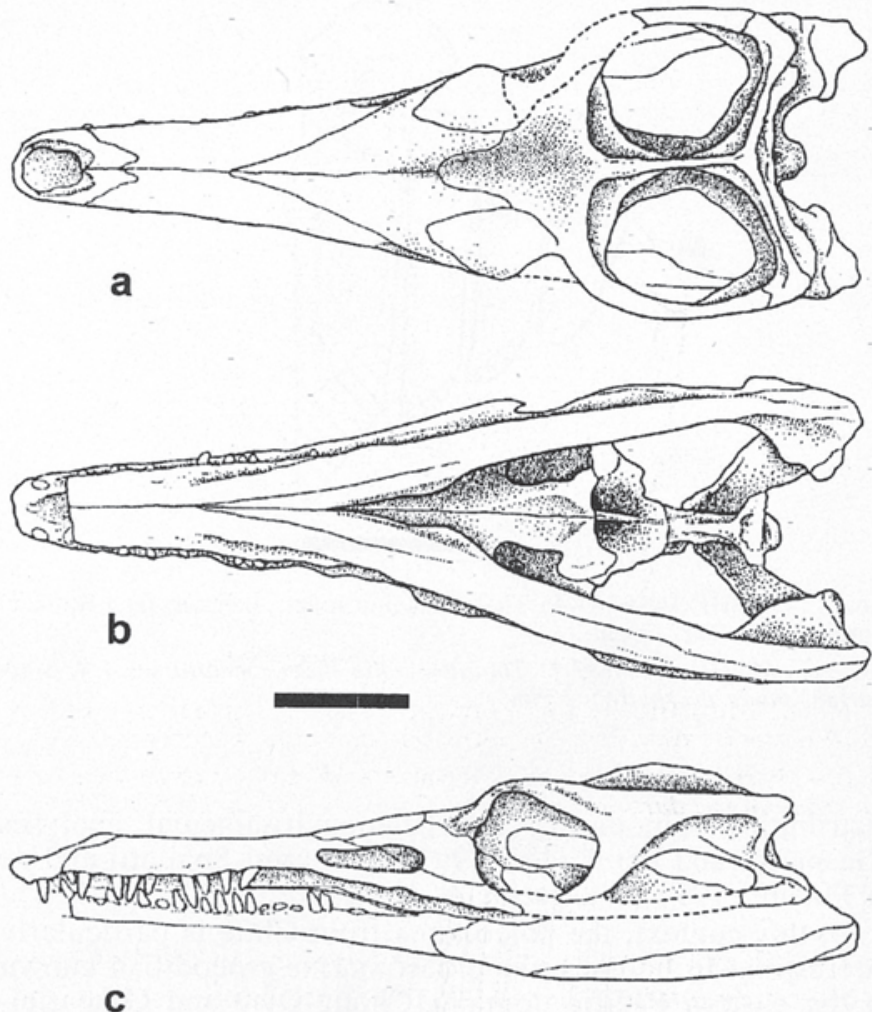

FIG. 4. - MGHF 1-08573, holotype, Metriorhynchus casamiquelai, Callovian. 3a, dorsal view; $3 \mathrm{~b}$, ventral view ; $3 \mathrm{c}$, lateral view, scale bar : $10 \mathrm{~cm}$. FIG. 4. - MGHF 1-08573, holotype, Metriorhynchus casamiquelai, Callovien. $3 a$, vue dorsale; $3 b$, vue ventrale; $3 c$, vue latérale, barre d'échelle $10 \mathrm{~cm}$.

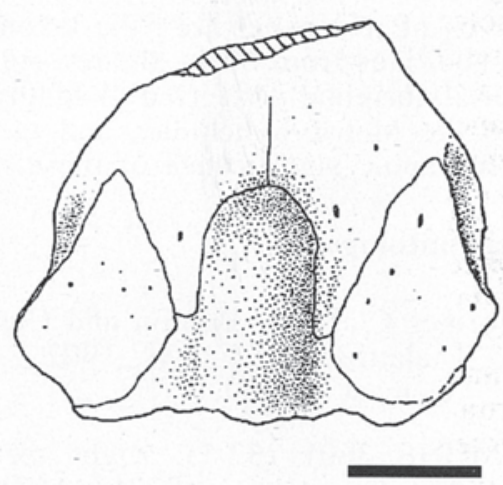

FIG. 5. - MGHF 181097 Metriorhynchus casamiquelai, Callovian, part of a skull in dorsal view, scale bar: $5 \mathrm{~cm}$.

FIG. 5. - MGHF 181097 Metriorhynchus casamiquelai, Callovien, fragment d'un crâne en vue dorsale, barre d'échelle: $5 \mathrm{~cm}$.

vian. MGHF 1-010199 (McMJ 1151r) original material (fig. 6) designed as $M$. westermanni holotype [Gasparini, 1980], from Placilla de Caracoles $\left(23^{\circ} 00^{\prime} \mathrm{S} ; 6^{\circ} 00^{\prime} \mathrm{W}\right)$ (fig. 1); Mina Chica Fm (Harrington), referred to the Lower-Middle Callovian [Gasparini, 1980]. The MGHF 1010199 was originally referred as McMJ $1151 \mathrm{r}$ from the Mc Master University (Canada). Currently it belongs to the Museo Geológico H. Fuenzalida, Chile.

The MGHF 1-181097 (fig. 5) extends from the antorbital wall to a brief section in front of the prefrontals. These are longer $(105 \mathrm{~mm})$ than wide $(80 \mathrm{~mm})$. The suture between 


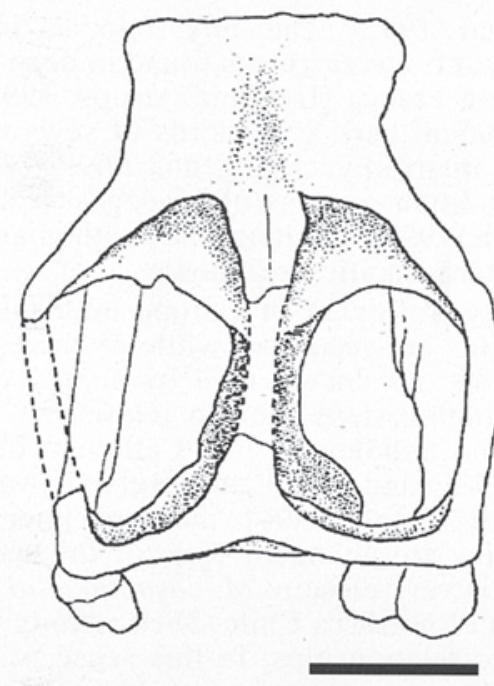

FIG. 6. - MGHF 1-010199 Metriorhynchus casamiquelai, posterior part of a skull in dorsal view, Early-Middle Callovian, scale bar: $5 \mathrm{~cm}$.

FIG. 6. - MGHF 1-010199 Metriorhynchus casamiquelai, partie postérieure d'un crâne en vue dorsale, Callovien inférieur ou moyen, barre d'échelle : $5 \mathrm{~cm}$.

the frontal and nasal has the same shape as in the holotype of $M$. casamiquelai. Likewise, they are alike in that the frontal is markedly deep between the orbits, and the prefrontals are smooth. The high porosity of the bones is worthy to be noted, suggesting the advanced osteoporosis of adults of metriorhynchids, ichthyosaurs and plesiosaurs [Hua and Buffrénil, 1996].

Discussion. - Adams-Tresman [1987] included M. casamiquelai in the synonymy of $M$. brachyrhynchus. In her opinion, the characters selected by Gasparini and Chong-Diaz [1977] to define $M$. casamiquelai (lack of ornamentation on the cranial and rostral bones; premaxillar-maxillar suture with form of an $\mathrm{M}$ ) are not valid because they exhibit a wide and continuous range of variation in Metriorhynchus. Adams-Tresman [op. cit. : 192] pointed out that there are faint striae on the nasals, and a portion of the frontal and prefrontal has been restored, reducing the amount of morphological details that can be retrieved from this vital area.

However, the frontal and the restored area of the right prefrontal is small and does not prevent inferring the complete lack of ornamentation. The specimen MGHF 1-181097 (fig. 5), 25 percent larger than the holotype, confirms the lack of ornamentation. Vignaud [1995] observed that in the brevirostral species of Metriorhynchus the ornamentation is progressively stronger in adults (specimens with skull and rostrum larger than $600 \mathrm{~mm}$ ). The holotype of $M$. casamiquelai is $618 \mathrm{~mm}$ in length and the new specimen is even longer.

Regarding the maxillary-premaxillary suture in dorsal view, both Adams-Tresman [1987] and Vignaud [1995] point out that it is V-shaped rather than W-shaped in Metriorhynchus. The latter is seen occasionally both in "broad-skulled" (brevirostrine) species such as $M$. brachyrhynchus and "narrow-skulled" species such as $M$. superciliosus [Adams-Tresman, 1987, Text-fig. 9; Vignaud 1995, fig. 37]. The shape of the suture is linked to the allometric growth of the anterior part of the rostrum [Vignaud, 1995]. While the V-shaped suture in most Thalattosuchia may respond to a dominant anteroposterior growth, the W-shaped suture may reflect a mediolateral growth, particularly significant in $M$. casamiquelai. Mediolateral growth is also observed in the fronto-nasal relationship and in the extreme development of the frontal between the orbits [Gasparini and Chong-Diaz 1977].

The specimen MGHF 1-181097 (fig. 5) is similar to the holotype of $M$. casamiquelai in the size and shape of the sutures of prefrontals, frontal and nasals. Despite being an older specimen, the anteroposterior length of the prefrontal is still larger than the mediolateral $(9.6 \mathrm{~cm} / 6.1 \mathrm{~cm})$. Likewise, the frontal extends between the nasals with a curved suture. A similar suture is seen in the specimen $B M(N H) R$ 3321 referred by Adams-Tresman [1987] and Vignaud [1995] to $M$. brachyrhynchus [Deslongchamps, 1868].

Among the "broad-skulled" species of Metriorhynchus (M. brachyrhynchus, sensu Adams-Tresman and $M$. brachyrhynchus and $M$. casamiquelai, sensu Vignaud), $M$. casamiquelai is the one in which the participation of the maxillae in the rostrum reaches its maximum. Consequently, it has the longest distance between nasals and premaxillae [Vignaud, 1995; fig. $57 \mathrm{f}$ ]. On the contrary, the nasals of some adults of $M$. brachyrhynchus extend anteriorly into the external nares [Leeds, 1908].

The frontal of $M$. casamiquelai is very distinct and its posterior base is very large. This particular shape of the frontal is an autapomorphy of the species, because it is proportionately much larger than any of the other species, independently of size of the animal [Vignaud, 1995: 145].

Vignaud [1995] recognized two morphotypes of internal nares in Callovian Metriorhynchidae. One of them is triangular, with the apex anteriorly directed, as in $M$. superciliosus. In the other morphotype the palatines form an $\mathrm{M}$ in the anterior edge of the nares $(M$. brachyrhynchus and $M$. casamiquelai). Though this character is slightly variable inter- and intraspecifically, the main difference is that $M$. $c a$ samiquelai has completely divided internal nares, closed posteriorly by a complete septum formed by the pterygoids (a character considered an autapomorphy). In other species of Callovian Metriorhynchus the nares open over the pterygoids.

The shape of the supratemporal fenestrae is linked to the allometric growth of the posterior part of the skull. When comparing individuals similar in size, the supratemporal fenestrae of $M$. casamiquelai are similar in length to those of the brevirostran species of Europe, but are much wider [Vignaud, 1995: 149]. In this way, the ratio of supratemporal fenestrae width versus skull length in skulls $570 \mathrm{~mm}$ and $680 \mathrm{~mm}$ long, is 18 percent in $M$. casamiquelai, 14 percent in $M$. brachyrhynchus (on 5 specimens), and 12 percent in $M$. supercilliosus (on 12 specimens).

Finally, the validity of $M$. casamiquelai claimed by $\mathrm{Vi}$ gnaud [1995] and Gasparini [1996] is here supported by the following unique derived features : posterior part of the frontal very wide, straight and perpendicular to the sagittal axis of the skull; completely divided internal nares closed posteriorly; nasals and premaxillae more widely separated; absence of ornamentation on the frontals and prefrontals.

The specimen MGHF 1-010199 (fig. 6), was designated the holotype of $M$. westermanni GASPARINI 1980. When this specimen was described, the mandible was attached with the skull [Gasparini, 1980, Plate I, II]. Now, the skull and the mandible are separated, and probably it has been treated with acid, as some of the characters mentioned in the original description cannot be observed.

The specimen MGHF 1-010199 (= M. westermanni), like $M$. casamiquelai, has no ornamentation (fig. 6). Although several authors [Buffetaut and Thierry, 1977; Adams-Tresman 1987; Vignaud 1995] do not accept this character because they consider it related either to sex or to ontogenetic development, in the Chilean specimens of Metriorhynchus 
it is independent of the size of the specimen. In this way, $M$. westermanni is approximately half the size of the holotype of $M$. casamiquelai, while the new specimen from Sierra Candeleros (MGHF 1-181097) is 25 percent larger than the holotype of $M$. casamiquelai. However, none of them has the ornamentation characteristic of any of the ornamented European species.

Other characters mentioned by Gasparini [1980] to support the validity of $M$. westermanni were : the lack of division in the internal nares, the position of the occipital table more vertical than in the holotype of $M$. casamiquelai, and the narrower postorbital pillar. The lack of division in the internal nares may be a consequence of poor preservation; however, the more vertical disposition of the occipital table [Vignaud, 1995] and the narrower postorbital pillar correspond to ontogenetic variations in extant crocodilians. Vignaud [1995: 229] pointed out that $M$. westermanni might be a synonym of $M$. casamiquelai. In this review, we conclude that it is a juvenile specimen of $M$. casamiquelai because of the two characters mentioned (vertical disposition of the occipital table and shape of the postorbital pillar).

\section{PALEOBIOGEOGRAPHIC APPROACH}

The remains of an indeterminant thalattosuchian found in the Sinemurian from Alto de Varas are the oldest records of marine crocodilians in the eastern Pacific. Although the record of early Jurassic marine crocodilians is scant, it demonstrates that they already inhabited the whole Tethys and the eastern Pacific. According to some paleogeographic reconstructions [Smith et al., 1995] the dispersal of these marine reptiles may have been circumpacific. However, an epicontinental Sinemurian corridor, in Central America (Caribbean or Hispanic Corridor) [Hillebrandt et al., 1992] may have aided on the dispersal of marine reptiles, in particular the crocodilians [Gasparini, 1978, 1985]. This seems to be the most plausible hypothesis, as the first marine crocodilians are Teleosauridae (probably the first crocodilian specimens of western South America were also Teleosauridae). Anatomical characters suggest that these forms must have been restricted to coastal environments and especially continental margins. Crossing the Paleopacific would have been an unsurmountable ecological barrier. The close affinities observed in some groups of ammonites, bivalves, brachiopods, and ostracods in western South America and western Europe have also been cited as evidence supporting the existence of an at least intermittent Caribbean Corridor, very early in the Jurassic [Schmidt-Effing, 1976; Hillebrandt 1981; Hallam, 1983; Manceñido and Dagys, 1992; Boomer and Ballent, 1996; Rubilar, 1998; Jakobs and Smith, 1998; Liu et al., 1998].

Some indeterminate fragments of plesiosaurs and ichthyosaurs, and the skull of Metriorhynchus sp. were found $100 \mathrm{~km}$ SSE from Copiapo, in early Bajocian levels [Jensen and Vicente, 1976]. Prior to this, the oldest records of Metriorhynchus came from the lower Callovian of Poitou, France [Vignaud et al., 1994]. Consequently, the specimen T.330 extends range of the metriorhynchids to the early Jurassic in the eastern Pacific. An unstudied skull, possibly related to Metriorhynchus, is reported from early Aalenian rocks of Oregon [Stricker and Taylor, 1989]. Previously, Buffetaut [1979] had described a Teleosauridae indet. from the early Bajocian of Oregon, though the material is too fragmentary to conclude its familial determination. Fossil crocodilians are scarce in the European Bajocian and belong mainly to teleosaurids, which is consistent with the regional regressions suggested age [Enay et al., 1980; Cariou et al.,
1985; Vignaud, 1995]. The only Bajocian metriorhynchid (Teleidosaurus cf. gaudryi) was found in deep-sea sediments of southeastern France [Hua and Atrops, 1995]. In the European Bathonian there are records of several teleosaurids, but a single metriorhynchid genus (Teleidosaurus), while the few crocodilian remains of Madagascar are Teleosauridae [Vignaud, 1995]. Hitherto no Bathonian crocodilians from the eastern Pacific are known.

In the early Callovian of Europe both teleosaurids and metriorhynchids are recorded, while in the eastern Pacific, thalattosuchians are documented by some vertebrae found in Oaxaca, southwestern Mexico [Gasparini, 1992]. But it is not until the middle and late Callovian of France [Hua et al., 1994; Vignaud 1995] and England [Adams-Tresman, 1987; Martill et al. 1994] that specimens referred to Metriorhynchus are abundant. One of the species, M. brachyrhynchus is very close to $M$. casamiquelai from the middle Callovian of northern Chile. Such affinity supports close biogeographic relationships. In this sense, it has been proposed that a Caribbean Corridor could be the dispersal route of Metriorhynchus and other marine reptiles [Gasparini, 1985, 1992; Gasparini and Fernández 1996], coincidental with the tecto-eustatic transgression of the beginning of the Callovian [Fourcade et al., 1995]. Marine Bajocian sediments have been recorded in northern Venezuela [Bartok et al., 1985] suggesting at least the existence of an arm of sea between North and South America. Again, the close taxonomic affinity among some ammonite, bivalve and brachiopod groups [Westermann and Riccardi, 1985; Manceñido and Dagys 1992; Rubilar, 1998] from the west of South America, and north of Africa and Europe support the hypothesis of the Caribbean corridor in the pre-Callovian middle Jurassic. Buffetaut [1979] also suggested the hypothesis of a Caribbean Corridor to explain the presence of marine crocodilians in the Bajocian of Oregon.

Finally, a marine crocodilian vertebra, similar to those of Geosaurus araucanensis, was found in the Tithonian of the Lo Valdés area, Chile. According to the paleogeographic reconstruction, this area belonged to the retroarc of Neuquén Basin [Legarreta and Uliana, 1991], where Geosaurus araucanensis is the most frequent Tithonian metriorhynchid of this basin. All the Tithonian crocodilians of the eastern Pacific come from the Neuquén Basin, and are exclusively metriorhynchids : Metriorhynchus potens (RUSCONi, 1948), Dakosaurus andiniensis VIGNAUD and GASPARINI, 1996 and Geosaurus araucanensis GASPARINI and DELLAPÉ, 1976. In accordance with the inferred habits [Hua, 1994; Hua and Buffetaut, 1997], they occur in off-shore facies of the Neuquén Basin [Gasparini et al., 2000]. In the European Tithonian Geosaurus and Dakosaurus are recorded in addition to teleosaurids [Buffetaut, 1982; Vignaud, 1995]. Toward the end of the Jurassic, and as a consequence of the fragmentation of Gondwana, other seaways opened and favored the dispersion of crocodilians and other marine reptiles together with the Caribbean Corridor [Gasparini, 1992; Gasparini and Fernández, 1997].

\section{CONCLUSIONS}

The first marine crocodilians of the eastern Pacific are recorded in the Sinemurian of northern Chile. Previous records of Liassic crocodilians of Chile and Argentina are dubious and cannot be determined at the family level [Gasparini, 1985]. If they were, as those of the European and Asian Lias, members of the family Teleosauridae, their transpacific dispersion was impossible, as the postcranium and osteoderms suggest that they had to live, at least in part, on land. In this case, the Liassic crocodilians of the 
Tethys may have had biogeographic connections with those of the eastern Pacific through intermittent Caribbean connections.

According to the record, it is quite probable that the Metriorhynchidae have been present in the late Aalenian of Oregon [Stricker and Taylor, 1989]. But it is in the early Bajocian of northern Chile when Metriorhynchus appeared, supporting the hypothesis of Vignaud [1995] of an extraTethyan origin for this genus. Besides, in this paper, $M$. westermanni GASPARINI, 1980 from the early-middle Callovian of Chile is considered a synonym of $M$. casamique $l a i$, also from the middle Callovian of northern Chile. Likewise, it is demonstrated that $M$. casamiquelai is a valid species, related to $M$. brachyrhynchus from the European Callovian [Vignaud, 1995; Gasparini 1996]. The close affinity between these species supports close paleobiogeographic relationships, and in this sense the Caribbean Corridor must have played a major role as it was for other nektonic organisms.
Finally, a vertebra probably referable to Geosaurus, found in the Tithonian of central Chile, expands westwards the rich record of Tithonian crocodilians of the Neuquén Basin, in which Geosaurus is the most common. Toward the end of the Jurassic the Caribbean Corridor could be still used as a dispersal route way by several pelagic reptiles, among them the metriorhynchid crocodiles. But other new seaways appeared, as a consequence of the fragmentation of Gondwana cannot be discarded. For example the Weddelian Corridor where ichthyosaurs have been recorded [Gasparini, 1992; Gasparini and Fernández, 1997].

Aknowledgements. - The authors thank the National Geographic Society for the Grant 6001/97 (to Z.G.). Likewise they thank Drs. Ernesto Pérez D'Angelo, Alfonso Rubilar (Geominas, Chile) and Reynaldo Charrier (Universidad de Chile, Santiago) for the biostratigraphic information; Dr. Marta Fernandez (Museo de La Plata), Mr. M. Lezcano for the drawings, Lic. C. Deschamps and D. Wharton for the English version and N. Bardet and J.-P. Bassoulet for commenting on the typescript.

\section{References}

Adams-Tresman S. (1987). - The Callovian marine crocodile Metriorhynchus from Central England. - Paleontology, 30 (1), 179-194.

Bartok P., Renz O. \& Westermann G. (1985). - The Siquesique ophiolites, northern Lara State, Venezuela : a discussion of the middle Jurassic ammonites and tectonics implications. - Geol. Soc. Amer. Bull., 96, 1050-1055.

Benton M.J. \& Clark J.M. (1988). - Archosaur phylogeny and the relationships of the Crocodylia. In : M.J. BEnton, Ed. The Phylogeny and classification of the Tetrapods. - Systematics Association., Sp. Vol. 35A, 295-338.

Boomer I. \& Ballent S. (1996). - Early-Middle Jurassic ostracod migration between the northern and southern hemispheres : further evidence for a proto Atlantic-Central America connection. - Palaeogeogr., Palaeoecol., Palaeoclimatol., 121, 53-64.

Brunet M. (1969). - Note préliminaire sur une faune de vertébrés du Callovien des environs de Poitiers. - C. R. Acad. Sci., Paris, 268, 2667-2670.

Buffetaut E. (1979). - Jurassic marine crocodilians (Mesosuchia, Teleosauridae) from Central Oregon, first record in North-America. - J. Pal., 53 (1), 210-215.

BufFETAut E. (1982). - Radiation évolutive, paléoécologie et biogéographie des crocodiliens Mésosuchiens. - Mém. Soc. géol. Fr., 142, $88 \mathrm{p}$.

Buffetaut E. \& ThierRy J. (1977). - Les crocodiles fossiles du Jurassique moyen et supérieur de Bourgogne. - Geobios, 10 (2), 151-194.

Cariou E., Contini D., Dommergues J.L., Enay R., Geyssant J., ManGOld C. \& ThierRy J. (1985). - Biogéographie des Ammonites et évolution structurale de la Téthys au cours du Jurassique. Bull. Soc. géol. Fr., (8), V, 679-697.

Casamiquela R. (1970). - Los Vertebrados jurasicos de la Argentina y de Chile. - Zoologia, Actas IV Congreso Latin, Venezuela, 1968, 2, 873-890.

Chong-Diaz G. \& Gasparini Z. (1972). - Presencia de crocodilia marino en el Jurasico de Chile. - Rev. Asoc. Geol. Argentina, 27 (4), 406-409.

Chong-Diaz G. \& Gasparini Z. (1976). - Los vertebrados mesozoicos de Chile y su aporte geopaleontologico. - Actas IV Congreso Geologico Argentino, Bahia Blanca 1975.

Deslongchamps J.A. (1868). - Note sur un tronçon de mâchoire supérieure d'une espèce nouvelle de Téléosaure. - Bull. Soc. Linn. Norm., (1866), 2 (1), 121-129.

Enay R., Mangold C., Cariou E., Contini D., Debrand-Passard S., Donze P., Gabilly J., Lefavrais-Raymond A., Mouterde R. \& THIERRY J. (1980). - Synthèse paléogéographique du Jurassique français. - Doc. Lab. Géol. Lyon, 5, 210 p.
FERNÁNDEZ M. (1997). - On the paleogeographic distribution of Callovian and late Jurassic ichthyosaurs. - J. Vert. Pal., 17(4), 752-754.

Fitzinger L. (1843). - Systema Reptilium. - Braumüller \& Seidel Eds. Wien, $106 \mathrm{p}$.

Fourcade E., Azéma J., Bassoullet J.P., Cecca F., Dercourt J., Enay R. \& Guiraud R. (1995). - Palaeogeography and palaeoenvironments of the Tethyan realm during Jurassic breakup of Pangea. $I n$ : A.E.M. NAIRM, J. Dercourt \& B. VRIELINCK Eds., The ocean basins and margins, vol. 8: The Tethys Ocean. Plenum Press, New York, 191-214.

FraAs E. (1902). - Die Meer-Crocodilier (Thalattosuchia) des oberen Jura unter specieller Berücksichtigung von Dacosaurus und Geosaurus. - Palaeontographica, 49, 1-79.

GASPARINI Z. (1978). - Consideraciones sobre los Metriorhynchidae (Crocodylia, Mesosuchia) : su origen, taxonomía y distribución geográfica. - Obras del Centenario del Museo de La Plata, 5, 1-9.

GASPARINI Z. (1980). - Un nuevo cocodrilo marino (Crocodylia, Mesosuchia) del Caloviano del norte de Chile. - Ameghiniana, 17 (2), 97-103.

Gasparini Z. (1981). - Los Crocodylia fósiles de la Argentina. - Ameghiniana, 18 (3-4), 177-205.

Gasparini Z. (1985). - Los reptiles marinos jurásicos de América del Sur. - Ameghiniana, 22 (1-2), 23-34.

Gasparini Z. (1992), - Marine reptiles of the Circum Pacific region. In : E.G. Westermann Ed., The Jurassic of the Circum Pacific. World and regional geology. - Cambridge Univ. Press, 3, 361364 .

GASPARINI Z. (1996). - Biogeographic evolution of the South American crocodilians. In : G. ARRATIA Ed., Contributions of southern South America on vertebrate paleontology. - Münch. Geowiss. Abh., A, 30, 159-184.

GASPARINI Z. (1997). - A new pliosaur from the Bajocian of Neuquen Basin, Argentina. - Palaeontology, 40 (1), 135-147.

Gasparini Z. \& ChONG-Diaz G. (1977). - Metriorhynchus casamiquelai n. sp. (Crocodylia, Thalattosuchia), a marine crocodile from the Jurassic (Callovian) of Chile, South America. - N. Jahrb. Geol. Paläont. Abh., 153 (3), 341-360.

Gasparini Z. \& Dellapé D. (1976). - Un nuevo cocodrilo marino (Thalattosuchia, Metriorhynchidae) de la Formación de Vaca Muerta (Jurásico, Titoniano) de la Provincia de Neuquén, República Argentina. - Actas I Congreso Geologico Chileno, 1, 1-22.

GASPARINI Z. \& FERnÁndeZ M. (1996). - Biogeographic affinities of the Jurassic marine reptiles fauna of South America. In: A. RIC CARDI Ed., Advances in Jurassic Research. - GeoResearch Forum, 1-2, Transtec Publication, 443-450. 
GASPARINI Z. \& FernándeZ M. (1997). - Tithonian marine reptiles of the Eastern Pacific. In : J.M. Callaway \& E.L. Nicholls Eds., Ancient marine reptiles. - Academic Press, San Diego, 435-450.

Gasparini Z. \& Spalletti L. (1993). - First Callovian plesiosaurs from the Neuquen Basin, Argentina. - Ameghiniana 30 (3), 245-254.

Gasparini Z., Spalletti L. \& de la Fuente M. (1997). - Tithonian marine reptiles of the Western Neuquén Basin, Argentina. Facies and palaeoenvironments. - Geobios, 30 (5), 701-712.

Gasparini Z, Spalletti L. \& Fernandez M. (1997). - Significado paleobiogeográfico de los reptiles marinos bajocianos (Jurásico medio) de la Cuenca Neuquina, Argentina. - VIII Congreso Geológico Chileno, Antofagasta 1997, 1, 484-488.

Gasparini Z., Spalletti L., Fernandez M. \& de la Fuente M. (2000). Tithonian marine reptiles from the Neuquen Basin: diversity and paleoenvironments. - Revue de Paléobiologie, 18 (1).

Hallam A. (1983). - Early and mid Jurassic molluscan biogeography and the establishment of the Central Atlantic Seaway. - Palaeogeogr. Palaeoecol. Palaeoclimatol., 43, 181-193.

Hillebrandt von A. (1977). - Ammoniten aus der Bajocian (Jura) von Chile (Sudamerika). - Mitt. Bayer. Staats. Paläont. hist. Geol., 17, 35-69.

HILlEBRANDT von A. (1981). - Kontinentalverschiebung und die paläozoogeographishen Beziehungen des südamerikanischen Lias. Geol. Rundsch., 70, 570-582.

Hillebrandt von A., Westermann E.G., Callomon J. \& Detterman R. (1992). - Ammonites of the Circum-Pacific region. In : E.G Westermann d., The Jurassic of the Circum-Pacific, World and Regional Geology. - Cambridge University Press, 342-359.

HuA S. (1994). - Hydrodynamique et modalités d'allègement chez Metriorhynchus superciliosus (Crocodylia, Thalattosuchia). - N. Jahr. Geol. Paläont. Abh., 193, 1-19.

HuA S. (1997). - Adaptations des crocodiliens mésosuchiens au milieu marin. - Mém. Sci. Terre. Univ. P. et M. Curie, Paris 6, 97-16, 1-209.

HuA S. \& Atrops F. (1995). - Un crâne de Teleidosaurus cf. gaudryi (Crocodylia, Metriorhynchidae) dans le Bajocien supérieur des environs de Castellane (Sud-Est de la France). - Bull. Soc. géol. Fr., 166 (6), 643-648.

Hua S. \& Buffetaut E. (1997). - Crocodylia. Introduction. In : J.M. CALLAWAY \& E.L. Nicholls Eds., Ancient Marine Reptiles. - Academic Press, San Diego, 357-374.

HuA S.\& BufFrénIL V. de. (1996). - Histology of the Thalattosuchia as a clue in the interpretation of functional adaptations in the Thalattosuchia (Reptilia, Crocodylia). - J. Vert. Pal., 16 (4), 703717.

Hua S., Vignaud P., Pennetier E. \& Pennetier G. (1994). - Un squelette de Steneosaurus obtusidens Andrews 1909 dans le Callovien de Villers-sur-mer (Calvados, France) et le problème de la définition des Teleosauridae à dents obtuses. - C. R. Acad. Sci., 2, 318, 1557-1562.

Huene F. von \& Maubeuge P.L. (1952). - Sur quelques restes de reptiles du Lias de Jeandelaincourt (Meurthe et Moselle). - Bull. Soc. géol. Fr., 6, II (1-3), 13-17.

Huene F. von \& Maubeuge P.L. (1954). - Sur quelques restes de Sauriens du Rhétien et du Jurassique lorrain. - Bull. Soc. géol. Fr., 6, IV (1-3), 105-109.

JAKoBs G. \& SMITH P. (1998). - The Hispanic Corridor and Toarcian ammonoid biogeography (Abstr.). In : Fifth International Symposium on the Jurassic System, Vancouver, 1998, 47.

Jensen O. \& Vicente J.C. (1976). - Estudio geológico del área de "Las Juntas" del Río Copiapó (Provincia de Atacama, Chile). - Rev. Asoc. Geol. Argentina, 31 (3), 145-173.

KRISHNA J. (1987). - Biological evidence for better appreciation of the Indian Gondwana. - The Paleobotanist, 36, 268-284.
KUHN-SCHNyDER E. (1960). - Ein Schädelfragment von Metriorhynchus aus dem unteren Callovien von La-Voulte (Ardèche-France). Eclogae Geol. Helv., 53 (2), 793-804.

KutTy S., JaIn S.L. \& Roy-Chowdhury T. (1987). - Gondwana sequence of the northern Pranhita-Godavari valley: its stratigraphy and vertebrate faunas. - The Paleobotanist, 36, 214-229.

LEEDS E.T. (1908). - On Metriorhynchus brachyrhynchus (DESL.) from the Oxford Clay near Peterborough. - Q. J. Geol. Soc., 64, 345-357.

Legarreta L. \& Uliana M. (1991). - Jurassic-Cretaceous marine oscillations and geometry of backarc basin fill, Central Argentine Andes. Sea level changes at active plate margins. - International Association of Sedimentologists, 12.

LI J. (1993). - A new specimen of Peipehsuchus teleorhinus from Ziliujing Formation of Daxion, Sichuan. - Vert. Palasiat., 31 (2), 4, 8594.

Liu C., Heinze M.\& Fürsich F.T. (1998). - Bivalve provinces in the Proto-Atlantic and along the southern margin of the Tethys in the Jurassic. - Palaeogeogr. Palaeoecol. Palaeoclimatol., 137, 127151.

MAnceñido M. \& Dagys A. (1992). - Brachiopods of the Circum-Pacific region. In : E.G. Westermann Ed., The Jurassic of the CircumPacific. World and regional geology. - Cambridge University Press, 3, 328-333.

Martill D.M., TaYlor M.A., Duff K.L., Riding J.B. \& Brown P.R. (1994). - The trophic structure of the biota of the Peterborough Member, Oxford Clay Formation (Jurassic). - J. Geol. Soc., 151, 173-194.

MEYer von H. (1830). - Achte Versammlung der Naturforscher und Aerzte zu Heidelberg im September 1829. - Isis v. Oken B. Mineral. Abt., 15 (2) 4/5/6, 517-519.

RUBILAR A. (1998). - La superfamilia Ostreacea en Chile y su importancia cronoestratigráfica, paleogeográfica y paleoecológica (Triásico superior-Jurásico). - Tésis Doctoral Facultad de Ciencias Naturales y Museo (UNLP), la Plata.

SChMidT-EFFing R. (1976). - Daten zur Entstehungsgeschichte von Golf, Karibik und Atlantik im Mesozoikum (Vorläufige Mitteilung). - Münster. Forsch. Geol. Paläont., 38/39, 201-217.

Smith A.G., Smith D.G. \& FunNel B.M. (1995). - Atlas of Mesozoic and Cenozoic coastlines. - Cambridge University Press, 99 p.

STRICKER L.S. \& TAYLOR D.G. (1989). - A new marine crocodile (Mesosuchia, Metriorhynchidae) from the Snowshoe Formation (Jurassic) Oregon. - J. Vert. Pal., 9 (3), 28, 40A.

TAVera J. (1981). - Ichthyosaurus de la Formación Lautaro, en el área de Manflas, región de Atacama, Chile. - Comunicaciones, Univ. de Chile, Departamento de Geología, 33, 1-16.

Vignaud P. (1995). - Les Thalattosuchia, crocodiles marins du Mésozoïque : systématique phylogénétique, paléoécologie, biochronologie et implications paléogéographiques. - Thèse de l'Université de Poitiers, $410 \mathrm{p}$.

Vignaud P., Broin de F., Brunet M., Cariou E., Hantzpergue P. \& LANGE-BADRÉ B. (1994). - Les faunes de vertébrés jurassiques de la bordure nord-orientale du bassin d'Aquitaine (France) : biochronologie et environnement. In : E. CARIOU \& P. HANTZPERGUE Eds., 3rd Intern. Symposium on Jurassic stratigraphy. Géobios, Lyon, 17, 493-503.

Vignaud P. \& GASPARINI Z. (1996). - New Dakosaurus (Crocodylomorpha, Thalattosuchia) in the Upper Jurassic of Argentina. - C. R. Acad. Sci., 322, 245-250.

Westermann G.E.G. \& Riccardi A.C. (1985). - Middle Jurassic ammonites evolution in the Andean province and emigration to Tethys. Sedimentary and evolutionary cycles. - Lectures Notes in Earth Sciences, Bayer \& Seilacher, Springer Berlin, 1, 6-34.

Young C.C. (1948). - Fossils crocodiles in China, with notes on dinosaurian remains associated with the Kansu crocodiles. - Bull. Geol. Soc. China, 28 (3-4), 255-288. 